\title{
THE REGULATION OF MIGRATION IN A TRANSITION ECONOMY: CHINA'S HUKOU SYSTEM
}

\author{
SHUMING BAO, ÖRN B. BODVARSSON, JACK W. HOU and YAOHUI ZHAO*
}

\begin{abstract}
Unlike most countries, China regulates internal migration. Access to public schools, health services, low-cost housing, and attractive jobs by those who do not have local registration (Hukou) is often limited. Coincident with the deepening of economic reforms, Hukou has gradually been relaxed since the 1980s, contributing to a migration surge. In this study of interprovincial Chinese migration, we address two questions. First, what is a sensible way of incorporating Hukou into theoretical and empirical models of migration in China? Second, to what extent has Hukou influenced the scale and structure of migration? We incorporate two different measures of Hukou into a modified gravity model nuanced to fit the Chinese case: (1) the migrant's perceived probability of securing Hukou and (2) the perceived joint probability of securing Hukou and a job available only to a registered person. Our tests include a much wider variety of controls especially important for the Chinese case. Using census data for 1985-90, 1995-2000, and 2000-05, we find that migration is very sensitive to Hukou, with the greatest sensitivity occurring during the middle period. (JEL J61)
\end{abstract}

\section{INTRODUCTION}

In most countries, internal migration is unregulated. That is not the case in China, where migration is restricted through a "Household Registration System," also called "Hukou." Instituted in 1958, Hukou required every citizen seeking a change in residence to obtain permission from the public security bureau. If

*We thank two anonymous referees, Wade Martin, and T.N. Srinivasan for helpful comments, as well as Ergan $\mathrm{Xu}$, Robert Girtz, and Li Lu for assistance with data collection. Zhao acknowledges support from the Key Research Base of the Humanities and Social Sciences of the Ministry of Education. The authors bear sole responsibility for any errors.

Bao: China Data Center, University of Michigan, 1810 South University Avenue, Ann Arbor MI 48109-1106; Lab for Urban and Regional Analysis, East China University of Science and Technology, Shanghai, China. Phone 734647 9610, Fax 734764 5540, E-mail sbao@ umich.edu

Bodvarsson: Department of Economics, Department of Management, St. Cloud State University, St. Cloud, MN 56301-4498; Institute for the Study of Labor (IZA), Bonn, Germany. Phone 320308 2225, Fax 320308 2228, E-mail obbodvarsson@stcloudstate.edu

Hou: Department of Economics, California State University_Long Beach, 120 Bellflower Blvd, Long Beach, CA 90840; School of Economics, Nankai University, Tianjin, China. Phone 562985 4710, Fax 562985 1121, E-mail jackhou@csulb.edu

Zhao: China Center for Economic Research, Beijing University, Beijing 100871, China; Institute for the Study of Labor (IZA), Bonn, Germany. Phone +8610-62754803, Fax +8610-62751474, E-mail yaohuizhao@gmail.com one wanted to move from a rural to urban area, for example he (or she) had to convert his (or her) local registration status from "agricultural" to "nonagricultural," an approval that was usually very difficult. ${ }^{1}$ It has also been very difficult to move from a small city to a large city under Hukou. Urban registration brings substantial benefits such as access to coveted jobs in the state sector, housing, public schooling, and health care. ${ }^{2}$ Hukou imposes both direct and indirect costs of relocation. For example, permanently leaving a village requires a migrant to abandon claims to land ownership and profits of village-owned industries. Hukou is effectively an internal passport system, as moving within or across provincial boundaries in China is analogous to moving across international boundaries.

1. Barriers to relocation are usually lower for persons admitted to university or recruited by the military.

2. Until the early 1990s, urban Hukou also entitled a person to "grain rations"-rations of necessities such as grain products and kerosene.

\section{ABBREVIATIONS}

CPI: Consumer Price Index

FAI: Foreign Asset Investment

FDI: Foreign Direct Investment

GDP: Gross Domestic Product

OLS: Ordinary Least Square

SSE: Sum of Squared Error 
Thus, for researchers interested in the study of how restrictions affect the scale and structure of worldwide migration, China is a tremendously valuable natural experiment.

Hukou has undergone an incremental dismantling over the last three decades. The history of this dismantling may be broken down into three periods - the 1980s, 1990s, and post-2000 period. ${ }^{3}$ Up to the late 1980 s, anyone wishing to travel within China had to show an official "permission" letter from his or her local government. Beginning in the late 1980s, identity cards replaced permission letters, making it much easier to travel. During the early 1990s, grain rationing coupons were abolished. These coupons had been the means by which people obtained food rations and they could only be used in the place of residence. In 2001, residency in small towns and townships was opened to all rural workers who were legally employed and had a place to live. At roughly the same time, medium-sized cities and some provincial capitals eliminated ceilings on the number of rural workers who could apply for permanent residence status or offer temporary registration for nonlocal residents. Some very large cities such as Shanghai and Beijing also eased restrictions on in-migration of nonlocal residents. ${ }^{4}$ Since census data on migration flows are available back to 1985-90, a test of deregulation's effects is feasible.

A small and mostly empirical literature on the determinants of internal migration in China has emerged. Its focus has been to examine the extent to which migration flows are driven by regional differences in labor markets. ${ }^{5}$ While most researchers recognize the influence of Hukou on Chinese migration patterns, no study

3. For more detailed history and analysis of Hukou, see Chan (1994), Chan and Zhang (1999), Cheng and Selden (1994), Day and Xia (1994), Goldstein (1990), Goldstein and Goldstein (1990), Wang (1997), Davin (1999), and Liang (2001).

4. There were other reforms at work too. First, rural workers were allowed to choose their sectors of employment. Second, in large coastal cities tax concessions, attractive terms for leasing land, economic development areas, and high technology development zones, were introduced.

5. The literature can be divided into studies utilizing micro-data obtained from special household surveys (e.g., Liang 2001; Liang and White 1996, 1997; Zhao 1997, 1999a, 1999b, 2002, 2003) and those utilizing province-level aggregate data (e.g., Fan 2005; Lin et al. 2004; Poncet 2006; and Bao et al. 2006). An entire issue of Urban Studies was devoted to China's growing migration and urbanization (see especially Chen and Coulson 2002; Liang, Chen, and Gu 2002; Li and Zahniser 2002; and Goodkind and West 2002). has attempted to estimate its effects on the scale and structure of migration. ${ }^{6}$ While there have been applications of the modified gravity model to the Chinese case, no study has estimated this model with a Hukou measure included. ${ }^{7}$ The most closely related study is Poncet (2006). She argued that as deregulation intensified, migration should have become more responsive to economic factors. Estimating a modified gravity model on migration data for 1985-90 and 1990-95, Poncet found that intra- and interprovincial migration rates were more responsive to spatial income and unemployment rate differences during 1990-95. However, she did not include a Hukou variable in either her theoretical model or empirical specifications. Furthermore, Poncet's coefficient estimates likely suffer from omitted variables bias because a number of important controls were absent. Missing controls include migrant networks, foreign and domestic investments, industry mix, demographic characteristics, climate, and educational attainment.

The goal of this study is twofold. First, we seek to estimate migration's sensitivity to Hukou. We incorporate several measures of Hukou into a modified gravity model of migration carefully nuanced to fit the Chinese case. Using data from the Chinese censuses and other sources, we test this model for the 1985-90, 1995-2000, and 2000-05 periods. Panel estimation is carried out as a means of evaluating how the sensitivity of migration to Hukou has changed over time. Second, we test our hypotheses using a more carefully nuanced and comprehensive model of migration than will be found in earlier studies. China has been experiencing a major transition from central planning to a market-based system. This transition has included large infusions of FDI and domestic fixed asset investments, considerable social and cultural changes, and tremendous growth in export markets, communications, and transportation infrastructure. China has also experienced very large growth in

6. Several recent studies examine other effects of Hukou. Au and Henderson (2006) developed a theoretical model and test to show that Hukou has led to undersized cities and losses in GDP. Whalley and Zhang (2004) used a simulation model to show that in the absence of restrictions, income inequality would have been much smaller. Wu and Treiman (2004) found that education and membership in the Communist Party are the most important factors affecting the odds of converting from rural to urban Hukou.

7. The migration literature generally lacks studies of migration's sensitivity to restrictions. A recent exception is Clark, Hatton, and Williamson's (2007) study of U.S. immigration. 
migrant networks, particularly in urban areas. Earlier studies have not adequately included controls for all these factors. Consequently, we believe our test provides the most complete and accurate picture of the scale and structure of migration in China.

The remainder of this article is organized as follows. Below we present a theoretical model of interprovincial migration flows and empirical specifications that include Hukou measures. We then describe our data set, followed by a presentation of the empirical results. The article concludes with a discussion of the implications of our findings for Western research on migration.

\section{A THEORETICAL MODEL OF MIGRATION}

Our theoretical model includes elements from the models of Poncet (2006), Crozet (2004), and Tabuchi and Thisse (2002). For simplicity, we assume just one potential destination. Worker $k$ from province $j$ must decide whether to relocate to province $i$ or stay home. Her objective is to choose the location for which the perceived quality of life, adjusting for all relocation costs, is higher. Perceived quality of life in a province is assumed to depend upon relative earnings opportunities, the probability of finding a job, and the availability of various amenities and nontradable goods. Amenities and nontradable goods could include, for example climate, the availability of ethnic goods and services, quality of schools, and public services. Furthermore, perceived quality of life will depend upon the size and proximity of a migrant network.

The migration decision will also depend upon migration costs, which are assumed to vary directly with distance. In the more general case where there are $R$ destination provinces (including $j$ ), the migrant's objective function is

$$
\text { (1) } \begin{aligned}
\Phi_{j i}^{k} & =W_{j i}^{k}+\eta_{i}^{k} \\
& =\ln \left[\pi_{i} Y_{i}\left(d_{i j}\right)^{-\psi}\right]+\eta_{i}^{k} \quad i \in[1, \mathrm{R}]
\end{aligned}
$$

where $\pi_{i}$ is the probability of securing employment in province $i, Y_{i}$ is real income in $i$, $d_{i j}$ is the geographic distance between home and host provinces, and $\eta_{i}^{k}$ is a stochastic term capturing all the other factors influencing the migrant's perceptions of the quality of life available in province $i$. Migration costs will rise proportionately with distance because as distance rises, the out-of-pocket costs of moving, the costs of acquiring information about labor market opportunities in the province, and the psychic costs of migration, will all be higher. In our simplified (one-destination) case, the decision boils down to comparing the two equations below and choosing the option associated with the higher-value equation:

(2) $\Phi_{i}^{k}=W_{i}^{k}+\eta_{i}^{k}=\ln \left[\pi_{i} Y_{i}\left(d_{i j}\right)^{-\psi}\right]+\eta_{i}^{k}$

(3) $\Phi_{j}^{k}=W_{j}^{k}+\eta_{j}^{k}=\ln \left[\pi_{j} Y_{j}\right]+\eta_{j}^{k}$.

As there are no migration costs associated with the "stay home" option (Equation (3)), real income, the probability of securing employment, and/or the migrant's perceptions of provincial characteristics in $i$, must be higher to overcome any explicit or implicit costs of moving there.

The migrant's comparison of the values of Equations (2) and (3) is equivalent to her calculating the expected net benefits of migration, $\Phi_{i}^{k}-\Phi_{j}^{k}$, and choosing to relocate only if those net benefits are positive. Taking the difference between Equations (2) and (3), the expected net benefits to migration are

$$
\text { (4) } \begin{aligned}
\Phi_{i}^{k}-\Phi_{j}^{k}= & {\left[\ln \left(\pi_{i}\right)-\ln \left(\pi_{j}\right)\right] } \\
& +\left[\ln \left(Y_{i}\right)-\ln \left(Y_{j}\right)\right]-\psi \ln \left(d_{i j}\right) \\
& +\left[\eta_{i}^{k}-\eta_{j}^{k}\right] .
\end{aligned}
$$

Equation (4) implies that the likelihood of migration will be higher: (1) the higher are expected relative income in $i$, the relative probability of securing employment in $i$, and the perceived relative favorability of other characteristics of $i$; and (2) the lower is distance. These are standard predictions implied by the economic theory of internal migration due originally to Sjaastad (1962) and Greenwood (1969).

In the home province, where the prospective migrant is assumed to have local Hukou, the probability of securing employment depends upon general labor market conditions, which are reflected in the provincial unemployment rate. Specifically, we posit that $\pi_{j}=g\left(u_{j}\right)$, where $u_{j}$ is the unemployment rate in the home province. In provinces where labor demand is relatively weak, the unemployment rate will be higher and it will be more difficult to find employment. With subscripts as derivatives, this implies that $g_{1}<0$.

In the destination province, the unregistered migrant can be hampered in finding a good job by two factors - general labor market conditions and the lack of household registration. Therefore, the probability of securing employment 
depends upon both the unemployment rate and the likelihood of obtaining Hukou:

$$
\pi_{i}=f\left[u_{i}, \operatorname{pr}\left\{H_{i}\right\}\right]
$$

where $u_{i}$ is the unemployment rate in province $i$ and $\operatorname{pr}\left\{H_{i}\right\}$ is the probability of obtaining Hukou there. It is assumed that $f_{1}<0$ and $f_{2}>0$. The reason for $f_{2}>0$ is that if a person lacks local Hukou, she will be shut out of certain parts of the labor market, that is, jobs in state enterprises and more high-skill and better-paying jobs. Having local Hukou not only provides one access to coveted jobs, but access to a greater variety of them. Even if the migrant doesn't care about securing Hukou, she may view the probability of securing Hukou as an indicator of the "openness" of the province. For example, provinces where it is harder to obtain local registration could be those that generally impose higher barriers to entry. There could also be an interaction effect between the unemployment rate and the likelihood of securing local Hukou $\left(f_{12} \neq 0\right)$. For example, suppose an export boom affecting all industries strengthens labor demand and lowers the unemployment rate. Although all workers will experience a higher likelihood of securing employment, those with local Hukou may experience an even bigger increase in the odds of landing a job because they have access to a greater variety of job opportunities $\left(f_{12}<0\right)$.

Incorporating $\pi_{j}=g\left(u_{j}\right)$ and Equation (5) into Equation (4), the expected net benefits to migration are now

$$
\begin{aligned}
\Phi_{i}^{k}-\Phi_{j}^{k}= & {\left[\operatorname { l n } \left(\pi_{i}\left(u_{i}, \operatorname{pr}\left\{H_{i}\right\}\right)-\ln \left(\pi_{j}\left(u_{j}\right)\right]\right.\right.} \\
& +\left[\ln \left(Y_{i}\right)-\ln \left(Y_{j}\right)\right]-\psi \ln \left(d_{i j}\right) \\
& +\left[\eta_{i}^{k}-\eta_{j}^{k}\right] .
\end{aligned}
$$

Equation (6) implies that the probability of migration is higher: (a) the higher is the unemployment rate in the home province; (b) the lower is the unemployment rate in the destination province; and (c) the higher is the perceived probability of obtaining local Hukou in the destination. In Section III, we work with several empirical specifications implied by Equation (6).

\section{EMPIRICAL SPECIFICATIONS}

The model above suggests a double-log empirical specification where the dependent variable is the log of the interprovincial migration rate $\left[\ln \left(M_{i j}\right)\right]$, which is the number of persons moving from province $j$ to province $i$ as a percentage of all persons moving out of province $j .{ }^{8}$ In using this specification for China, we include explanatory variables from an assortment of studies, including Lin et al. (2004), Bao et al. (2006), and Poncet (2006). Our empirical specification extends previous research in several important ways. First, we add controls for Hukou. Second, we add other measures which are important for the study of the Chinese test case. Third, ours is a panel study spanning three periods.

We estimate three specifications. The first is a panel version of a basic specification due originally to Greenwood $(1969,1997)$ and applied to the Chinese case by Lin et al. (2004):

$$
\begin{aligned}
\ln \left(M_{i j t}\right)= & \alpha_{0}+\alpha_{1} \ln \left(Y_{j i t}\right)+\alpha_{2} D_{i j} \\
& +\alpha_{3} \ln \left(\pi_{i t}\right)+\alpha_{4} \ln \left(\pi_{j t}\right) \\
& +\sum_{x=1}^{q} \beta_{x} \ln \left(Z_{x t}\right)+\sum_{t=1}^{T-1} \lambda_{t} \text { Period }_{t} \\
& +\sum_{p=1}^{Z-1} \theta_{p} \text { Province }_{p}+\varepsilon_{i j t},
\end{aligned}
$$

where $Y_{j i t}=$ the ratio of destination province to origin province income in period $t$;

$D_{i j}=$ geographic distance between provinces;

$\pi_{i t}\left(\pi_{j t}\right)=$ the probability of securing employment in the destination (origin) province in period $t$;

$Z_{x t}=$ other controls for perceived quality of provincial life, in period $t$;

Period $_{t}=$ time period during which migration occurred, where there are $T$ periods;

Province $_{p}=$ origin province fixed effect, where there are $Z$ provinces;

$\varepsilon_{i j t}=$ random error term; and

the $\alpha, \beta, \lambda$, and $\theta$ parameters are coefficients to be estimated.

We hypothesize that $\alpha_{1}>0, \alpha_{2}<0, \alpha_{3}>0$, and $\alpha_{4}<0$.

The next two empirical specifications are extensions of Equation (7). Where they differ is in how Hukou restrictions are measured. Before describing each equation, it is important to note that in China unemployment rates are estimated using data only on locally registered persons. ${ }^{9}$

8. This specification, widely used in the literature, is due originally to Greenwood (1969).

9. Undocumented migrants (also called members of the "floating population") are not included. 
Therefore, the official provincial unemployment rate measures unemployment risk for a registered person only. Define $u_{i t}\left(u_{j t}\right)$ as the reported unemployment rate in the destination (origin) province. It follows that $\left(1-u_{\text {it }}\right)$ is the probability of securing employment in the destination province when a person is registered there and $\left(1-u_{j t}\right)$ is the probability in the origin province.

The first equation measures Hukou as simply the odds of securing local registration:

$$
\begin{aligned}
\ln \left(M_{i j t}\right)= & \alpha_{0}+\alpha_{1} \ln \left(Y_{j i t}\right)+\alpha_{2} D_{i j}+\alpha_{3} \\
& \times \ln \left(1-u_{i t}\right)+\alpha_{4} \ln \left(\text { Hukpercent }_{i t}\right) \\
& +\alpha_{5} \ln \left(1-u_{j t}\right)+\sum_{x=1}^{q} \beta_{x} \ln \left(Z_{x t}\right) \\
& +\sum_{t=1}^{T-1}\left[\left(\lambda_{t} \text { Period }_{t}\right)+\chi_{t}\left(\left(\text { Period }_{t}\right)\right.\right. \\
& \left.\left.\times \ln \left(\text { Hukpercent }_{i t}\right)\right)\right] \\
& +\sum_{p=1}^{Z-1} \theta_{p} \text { Province }_{p}+\varepsilon_{i j t}
\end{aligned}
$$

where "Hukpercent" is the probability of securing local Hukou. Given available data, we measure Hukpercent as the lagged relative frequency of registered households. It is assumed that prospective migrants know the historical relative frequencies of registered households in their prospective destinations and have adaptive expectations about barriers to entry. We hypothesize that $\alpha_{4}>0$, implying that when the likelihood of securing Hukou rises, the migration rate will rise. The second equation measures Hukou as the joint probability of an unregistered migrant securing Hukou and securing a job available only to someone with Hukou. This measure equals one minus the unemployment rate in the destination times the historical relative frequency of registered households:

$$
\begin{aligned}
\ln \left(M_{i j t}\right)= & \alpha_{0}+\alpha_{1} \ln \left(Y_{j i t}\right) \\
& +\alpha_{2} D_{i j}+\alpha_{3}\left[\ln \left(1-u_{i t}\right)\right. \\
& \left.\times \ln \left(\text { Hukpercent }_{i t}\right)\right]+\alpha_{5} \ln \left(1-u_{j t}\right) \\
& +\sum_{x=1}^{q} \beta_{x} \ln \left(Z_{x t}\right)+\sum_{t=1}^{T-1}\left[\lambda_{t} \text { Period }_{t}\right. \\
& +\chi_{t}\left(( \text { Period } _ { t } ) \left(\ln \left(1-u_{i t}\right)\right.\right.
\end{aligned}
$$

$$
\begin{aligned}
& \left.\left.\times \ln \left(\text { Hukpercent }_{i t}\right)\right)\right] \\
& +\sum_{p=1}^{Z-1} \theta_{p} \text { Province }_{p}+\varepsilon_{i j t} .
\end{aligned}
$$

While one minus the unemployment rate measures the likelihood of a registered migrant securing a job, weighting that likelihood by the likelihood of securing Hukou accounts for the fact that unregistered migrants find it more difficult to secure employment in the destination than those who are registered, all other things equal. It is hypothesized that $\alpha_{3}$ in Equation (9) is positive.

Another way of looking at the difference between Equations (8) and (9) is that in (9), Hukou is relevant to the migrant only if it impacts the odds of securing employment in the destination. In contrast, Equation (8) includes a more expansive measure of Hukou, reflecting the notion that the benefit of local Hukou goes beyond getting a good job. Being registered means having access to other kinds of benefits in the destination.

The interactions between the time dummies and the relative frequency of registered households $\left[\left(\right.\right.$ Period $\left._{t}\right)\left(\operatorname{Ln}\left(\right.\right.$ Hukpercent $\left.\left._{i t}\right)\right]$ describe the time-varying effects of Hukou on the incentive to migrate. If the odds of obtaining Hukou affect the incentive to migrate differently for different periods, this will be reflected in positive or negative values of the $\chi_{t}$ coefficients in Equations (8) and (9). The Hukou system has been relaxed incrementally over the last three decades, with some provinces reducing barriers to local registration more than others. Greater deregulation may have lowered the perceived relevance of securing Hukou to the migration decision and caused the migration rate to be less sensitive to the odds of securing Hukou. In that case, $\lambda_{t}$ will be negative. On the other hand, if greater ease of transportation and communication reduced migration costs, and macroeconomic reforms combined with growing prosperity substantially stimulated migration, then having local registration may be more important than before. In that case, $\lambda_{t}$ will be positive.

Other controls (the $x$ 's) included are described below along with hypothesized signs on the regression coefficients. Commentary is provided for some controls:

1. Log size of the migrant community in the destination that migrated before from the origin, as a percent of the destination's population $(>0)$. 
2. Log ratio of real Foreign Direct Investment (FDI) or Foreign Asset Investment (FAI) per capita in the destination to real FDI (FAI) per capita in the origin $(>0)$.

Higher investment in the destination will pull in migrants from other provinces, but diminish the incentive for residents of the destination to leave.

3. Interaction of the log ratio of real FDI and the log ratio of real FAI.

The two ratios are interacted to control for the possibility that higher levels of one investment type may influence the marginal effect of the other on the migration rate. For example, foreign firms investing in a province tend to compete for the same pool of workers as do domestic firms. Suppose there is higher FDI in the destination which pulls migrants in to FDI-financed firms. Now the pool of migrants available to FAIfinanced firms will be lower, hence the ability of higher FAI to attract migration will be lower.

4. Log percentages of population enrolled in the origin's universities ${ }^{10}(<0)$ and the destination's universities $(>0)$.

A better-educated labor force often means higher quality employment opportunities.

5. Log ratio of the share of manufacturing employment in the destination to the share of manufacturing employment in the origin $(>0)$.

This ratio controls for industrial composition. Manufacturing jobs are generally higher-paying compared to agricultural jobs, thus provinces with larger manufacturing sectors should have higher in-migration rates, all other things equal.

6. Log ratio of the urban share of the destination province's population to the urban share of the origin province's population $(>0)$.

This ratio controls for the characteristics of provinces with higher population densities. For example, more urbanized provinces will have different amenities, employment opportunities, and standards of living, from more rural provinces.

7. Log ratio of the destination province's minority population share ${ }^{11}$ to the origin province's minority population share $(>0$ or $<0)$.

10. A better measure of educational attainment is the percentage of the population that is college-educated; however, that is not available for individual provinces.

11. The proportion of a province's population that is a minority was computed in the following way: minority share $=\left(\frac{\text { total population }- \text { Han population }}{\text { total population }}\right) \times 100$.
First, provinces with larger minority populations may be more politically divisive, which may discourage in-migration. Second, as Bao et al. (2006) suggest, provinces with more minorities tend to lack basic service industries, which may attract entrepreneurial migrants who establish firms providing basic services. Third, highskill professionals may have a lower incentive to migrate to provinces with higher minority shares because high-skill employment opportunities may be more limited there.

8. Log ratio of mean yearly temperature in the capital city of the destination province to mean yearly temperature in the capital city of the origin province $(>0)$.

9. Log share of real FAI in the origin province devoted to transportation $(<0)$.

When there are greater investments to expand and upgrade railroads, airports, and highways, the costs of relocating will fall.

10. Interaction of the log of real FAI and real per capita Gross Domestic Product (GDP) in the origin $(>0)$.

Recall that an increase in FAI is hypothesized to reduce out-migration. In poorer provinces, where state-sponsored investment spending is usually much lower to begin with, the marginal productivity of new investment and the resulting increase in labor demand may be much higher. Consequently, the out-migration rate may fall relatively more in poorer provinces than in richer ones.

11. Interaction of the $\log$ of relative past migration flows (item 1 above) and $\log$ of distance $(>0)$.

For a long distance move, the migrant will place greater value on the destination's migrant community for assistance with relocation.

\section{DISCUSSION OF DATA}

Our data are drawn from two major sources. For the 1985-90 and 1995-2000 periods, we expand the data set used by Lin et al. (2004) to include data on new regressors. ${ }^{12}$ All data are taken from the University of Michigan's China

12. Note that we replaced Lin et al.'s (2004) calculations of the dependent variable with our own calculations. The reason is that there are some inaccuracies in the series used by Lin et al., which they acknowledged in communications with us. 
TABLE 1

Summary Statistics for 1985-90 Period 765 Observations

\begin{tabular}{|c|c|c|c|c|}
\hline Variable & Mean & Standard Deviation & Maximum & Minimum \\
\hline Migration rate $\times 100^{\mathrm{a}}$ & 3.775 & 6.982 & 79.336 & 0.018 \\
\hline $\begin{array}{l}\text { Mean annual percentage of } \\
\text { households with Hukou status } \\
\text { during } 1980-84 \times 100\end{array}$ & 98.40 & 1.412 & 99.73 & 94.94 \\
\hline $\begin{array}{l}\text { Real mean annual FDI per } \\
\text { capita during } 1980-84^{\text {b }}\end{array}$ & \$US 1.544 & \$US 5.947 & \$US 31.75 & \$US 0.0038 \\
\hline $\begin{array}{l}\text { Real mean annual fixed asset } \\
\text { investment }(\mathrm{FAI}) \text { per capita } \\
\text { during } 1980-84^{\mathrm{C}}\end{array}$ & 163.77 Yuan & 132.84 Yuan & 518.71 Yuan & 40.888 Yuan \\
\hline $\begin{array}{l}\text { Percentage of provincial FAI } \\
\text { attributable to transportation } \\
\text { infrastructure } \times 100\end{array}$ & 3.67 & 1.85 & 8.82 & 1.07 \\
\hline $\begin{array}{l}\text { Railway distance between } \\
\text { capital cities }\end{array}$ & 1,630.76 KM & $1.87 \mathrm{KM}$ & $6,313.21 \mathrm{KM}$ & $137 \mathrm{KM}$ \\
\hline Real annual per capita income ${ }^{c}$ & 510.95 Yuan & 183.11 Yuan & 1084.5 Yuan & 340.53 Yuan \\
\hline $\begin{array}{l}\text { Percentage of population } \\
\quad \text { enrolled in universities } \times 100\end{array}$ & 0.2499 & 0.2649 & 1.3 & 0.08 \\
\hline Unemployment rate $\times 100$ & 1.178 & 0.705 & 4.11 & 0.28 \\
\hline $\begin{array}{l}\text { Manufacturing share of } \\
\text { employment } \times 100\end{array}$ & 23.44 & 12.10 & 59.3 & 9.47 \\
\hline Urban share of population $\times 100$ & 31.03 & 16.17 & 73.44 & 14.87 \\
\hline Mean yearly temperature & $14.113 \mathrm{C}$ & $5.176 \mathrm{C}$ & $24.517 \mathrm{C}$ & $4.608 \mathrm{C}$ \\
\hline Minority population share $\times 100$ & 12.28 & 16.06 & 59.43 & 0.31 \\
\hline
\end{tabular}

an the 1990 Census, a migrant is defined as someone who has moved from other jiedao, town, or township and has lived in this place for more than 1 year but less than 5 years. The migrants counted in this table are for interprovincial migration only.

${ }^{\mathrm{b}}$ Computed using average annual CPI for $1980-84$.

${ }^{\mathrm{c}}$ Computed using income and CPI for 1989 only.

Data Online website (http://www.chinadataonline.org/). Our data set includes 2,425 observations, of which 40 with a zero migration rate were excluded, for 29 provinces. There are 790 observations for 1985-90, 765 for 1995-2000, and 790 for $2000-05 .{ }^{13}$ Destination migrant stock data are unavailable for 1985-90 because that is the first period for which information on migration is available. However, for the subsequent periods we were able to create observations for the relative size of the destination's migrant network. We thus produced two sets

13. We skipped the 1990-95 period of migration for an important reason. One of our objectives is to test for structural changes in the migration equation between time periods in postreform China. One question posed by this study is: As the reforms deepened, especially as the easing of barriers to mobility intensified, did the structure of migration change? We contend that imposing a 5-year break in the data makes it easier to ascertain whether or not structural change occurred. Furthermore, the structure of China's postreform labor market has been changing at an exponential pace, with at least as much (if not more) structural change occurring between 1995-2000 and 2000-05 as between 1985-90 and 1995-2000. Therefore, imposing the 5-year break when comparing the 1980s and 1990s, as opposed to no break between the 1990s and 2000s, should not bias the coefficient estimates. of estimates: (1) estimates for the full panel with no migrant stock and (2) estimates for a smaller panel comprising the later two periods with migrant stock (1,580 observations).

Tables $1-3$ show summary statistics. Starting from the top, we describe the variable, its data source, and trends:

1. Gross interprovincial migration rate: For 1985-90, 1995-2000, and 2000-05, respectively, migration rates are calculated from samples comprising $1 \%$ of the 1990 population census, $0.95 \%$ of the 2000 census, ${ }^{14}$ and $1 \%$ of the 2005 census. In the

14. As pointed out by Lin et al. (2004, p. 593), there is a small difference between the 1990 and 2000 censuses with respect to how migration flow is defined. If a person is observed to change residence and to change their household registration ("Hukou migration"), this is classified as migration in both censuses. If, however, the person is observed to change residence without changing registration ("non-Hukou migration"), this is classified as "Hukou migration" only if the migrant has been away from the place (jiedao, town or township) of registration for a minimum period and less than 5 years. In the 1990 (2000, 2005) census, the minimum period is 1 year (6 months). To account for this change in classification between periods, migration statistics were standardized by discounting the 2000 numbers by approximately $5 \%$. 
TABLE 2

Summary Statistics for 1995-2000 Period 790 Observations

\begin{tabular}{|c|c|c|c|c|}
\hline Variable & Mean & Standard Deviation & Maximum & Minimum \\
\hline Migration rate $\times 100^{\mathrm{a}}$ & 3.589 & 7.230 & 87.317 & 0.014 \\
\hline $\begin{array}{l}\text { Mean annual percentage of } \\
\text { households with Hukou status } \\
\text { during } 1990-94 \times 100\end{array}$ & 90.38 & 5.443 & 96.01 & 74.97 \\
\hline $\begin{array}{l}\text { Past migration flows during } \\
\quad 1985-95\end{array}$ & $2,498,500$ & $6,854,100$ & $89,320,000$ & 10,000 \\
\hline $\begin{array}{l}\text { Real mean annual FDI per capita } \\
\text { during } 1990-94^{\text {b }}\end{array}$ & \$US 16.14 & \$US 24.25 & \$US 92.73 & \$US 0.58 \\
\hline $\begin{array}{l}\text { Real mean annual fixed asset } \\
\text { investment (FAI) per capita } \\
\text { during } 1990-94^{\text {b }}\end{array}$ & 871.66 Yuan & 717.63 Yuan & 3393.2 Yuan & 229.7 Yuan \\
\hline $\begin{array}{l}\text { Percentage of provincial FAI } \\
\text { attributable to transportation } \\
\text { infrastructure } \times 100\end{array}$ & 5.48 & 2.04 & 11.07 & 2.81 \\
\hline Real annual per capita income ${ }^{c}$ & 1,069 Yuan & 442.2 Yuan & 2,451.5 Yuan & 605.26 Yuan \\
\hline $\begin{array}{l}\text { Percentage of population enrolled in } \\
\text { universities } \times 100\end{array}$ & 0.3769 & 0.3329 & 1.7 & 0.13 \\
\hline Unemployment rate $\times 100$ & 4.40 & 2.41 & 9.64 & 1.36 \\
\hline $\begin{array}{l}\text { Manufacturing share of employment } \\
\quad \times 100\end{array}$ & 22.83 & 9.82 & 49.25 & 9.17 \\
\hline Mean yearly temperature $\left({ }^{\circ} \mathrm{C}\right)$ & 14.113 & 5.176 & 24.517 & 4.608 \\
\hline Urban share of population $\times 100$ & 40.20 & 18.56 & 90.67 & 18.63 \\
\hline Minority population share $\times 100$ & 12.28 & 16.06 & 59.43 & 0.31 \\
\hline
\end{tabular}

${ }^{\text {a In the }} 2000$ Census, a migrant is defined as someone who has moved from other jiedao, town, or township and has lived in this place for more than 6 months but less than 5 years. The migrants counted in this table are for interprovincial migration only.

${ }^{\mathrm{b}}$ Computed using average annual CPI for 1990-94.

${ }^{\mathrm{c} C}$ Computed using income and CPI for 1999 only.

1990 (2000, 2005) census, respondents were asked to report on mobility during 1985-90 (1995-2000, 2000-05, respectively). Mean emigration surged from over 355,000 persons during 1985-90 to over 1,075,000 during 1995-2000, and to over 2,200,000 during $2000-05 .^{15}$ Note that mean provincial population rose by $9.44 \%(5.86 \%)$ between 1990 and 2000 (between 2000 and 2005). For the first two periods, Sichuan had the largest emigration level (approximately 1,457,000 persons during 1985-90 and 4,375,000 during 1995-2000), while Ningxia had the lowest (approximately 54,500 persons during $1985-90$ and 94,750 during 1995-2000). During 1985-90, the highest migration rate was $79.34 \%$ (Guangxi to Guangdong) and the lowest was $0.02 \%$ (a tie between Jiangxi to Qinghai and Jiangxi to Ningxia). During 1995-2000, the highest migration rate was $87.32 \%$ (Guangxi to Guangdong)

15. There are likely to be discrepancies in the calculations of these numbers between decades, for the reasons discussed earlier. and the lowest was $0.14 \%$ (Jiangxi to Qinghai). For 2000-05, the highest in-migration rate was $36.53 \%$ (Guangdong) and the lowest was $0.19 \%$ (Qinghai). The highest out-migration rate was $20.54 \%$ (Gansu) and the lowest was $0 \%$ (Xinjiang).

2. The historical relative frequency of persons with local Hukou: This is the ratio of registered population to total population at year's end. For the 1985-90 (1995-2000, 2000-05) period, we used the mean annual proportion of persons with Hukou during 1980-84 (1990-94, 1995-99, respectively). There are two reasons we used the lagged proportion registrations. First, this measure is consistent with its theoretical counterpart (the lagged relative frequency of persons with Hukou). Second, there is likely two-way causality between in-migration and current registrations in the destination. By using the lagged proportion of registrations we avoid simultaneous equations bias.

Tables 1-3 indicate interesting patterns over time with respect to the proportion of 
TABLE 3

Summary Statistics for 2000-05 Period 790 Observations

\begin{tabular}{|c|c|c|c|c|}
\hline Variable & Mean & Standard Deviation & Maximum & Minimum \\
\hline Migration rate $\times 100^{\mathrm{a}}$ & 3.655 & 7.387 & 87.32 & 0.01 \\
\hline $\begin{array}{l}\text { Mean annual percentage of } \\
\text { households with Hukou status } \\
\text { during } 1995-99 \times 100\end{array}$ & 88.57 & 6.726 & 95.85 & 67 \\
\hline $\begin{array}{l}\text { Real mean annual FDI per } \\
\text { capita during } 1995-99^{\mathrm{b}}\end{array}$ & \$US 44.64 & \$US 66.57 & \$US 253.05 & \$US 1.15 \\
\hline $\begin{array}{l}\text { Real mean annual fixed asset } \\
\text { investment (FAI) per capita } \\
\text { during } 1995-99^{\mathrm{b}}\end{array}$ & $2,452.8 \mathrm{Y}$ & $2,441.5 \mathrm{Y}$ & $12,705 \mathrm{Y}$ & $646.5 \mathrm{Y}$ \\
\hline $\begin{array}{l}\text { Percentage of provincial FAI } \\
\text { attributable to transportation } \\
\text { infrastructure } \times 100\end{array}$ & 9.2 & 3.06 & 17.19 & 3.98 \\
\hline Real annual per capita income ${ }^{c}$ & $5,122.3 \mathrm{Y}$ & $2,632.7 \mathrm{Y}$ & $13,484 \mathrm{Y}$ & $2,614.6 \mathrm{Y}$ \\
\hline $\begin{array}{l}\text { Percentage of population } \\
\quad \text { enrolled in universities } \times 100\end{array}$ & 0.9985 & 0.5985 & 3.06 & 0.4 \\
\hline Unemployment rate $\times 100$ & 3.14 & 1.50 & 7.17 & 1.21 \\
\hline $\begin{array}{c}\text { Manufacturing share of } \\
\text { employment } \times 100\end{array}$ & 22.83 & 9.82 & 49.25 & 9.17 \\
\hline Mean yearly temperature $\left({ }^{\circ} \mathrm{C}\right)$ & 14.27 & 5.24 & 25.1 & 4.70 \\
\hline Urban share of population $\times 100$ & 40.20 & 18.56 & 90.67 & 18.63 \\
\hline Minority population share $\times 100$ & 12.83 & 16.47 & 60.13 & 0.31 \\
\hline
\end{tabular}

${ }^{a}$ In the 2005 Census, a migrant is defined as someone who has moved from other jiedao, town, or township and has lived in this place for more than 6 months but less than 5 years. The migrants counted in this table are for interprovincial migration only.

${ }^{\mathrm{b}}$ Computed using average annual CPI for 1995-99.

${ }^{\mathrm{c}}$ Computed using average annual income and CPI for 2000-05.

registered persons. First, note that despite Hukou undergoing gradual relaxation, the proportion of registered persons fell from an average of $98 \%$ during the early 1980 s to an average of $88.5 \%$ during 2000-05. This is probably because nonHukou migrant flows grew faster than the number of registered households. Second, the variance of registrations across provinces rose appreciably across decades. The spread between the minimum and maximum percentages during $1980-84$ was $4.79 \%$, but soared to $21.04 \%$ during 1990-94 and $28.85 \%$ during 1995-99. This means that provincial differences in barriers to Hukou, hence the incentives to migrate, rose substantially.

3. Migrant stock: Migrant stock is usually measured as relative size of the accumulated migrant community. Unfortunately, this measure is unavailable for China, so we used past flows. For 1995-2000 (2000-05), migrant stock equals migrant flows from provinces $\mathrm{i}$ to $\mathrm{j}$ during 1985-95 out of j's population in 2000 (2005). It is presumed that the stock of previous migrants is proportional to previous flows.
4. Real annual per capita FDI and FAI: We used mean annual real FDI (FAI) per capita during 1980-84 when regressing 1985-90 migration flows, 1990-94 mean annual real FDI (FAI) per capita when regressing 1995-2000 flows, and 1995-99 mean real FDI (FAI) per capita when regressing 2000-05 flows. Investment was lagged because it takes time for migration to respond to changes in investment. Furthermore, since two-way causality between investment and migration is likely, regressing migration on lagged investment allows one to avoid simultaneous equations bias. Investment data were adjusted for cost of living differences using national government measures of provincial Consumer Price Index (CPI) and a 1985 base year. For most provinces, FDI was available yearly, but for some provinces there were gaps in the data. No investment data were available for 1980-84 for several provinces, so we used the earliest year available as a proxy. FDI data are in U.S. dollars, whereas fixed asset data are in Yuan. Comparing Tables 1-3, FAI and FDI rose dramatically. Areas experiencing the most investment tended to be large cities, 
whereas rural areas had the smallest amounts of investment.

5. The share of manufacturing employment: Manufacturing is classified in China as a "Secondary" industry and construction is a big component. There are substantial provincial differences in manufacturing share. For all three periods, Shanghai had the highest share and Hainan the lowest.

6. Minority population share: This is the percentage of non-Han population. Data on Han population shares for 1990 are not available, so we used 2000 data to proxy minority population shares for the first two migration periods. For 2000-05, we used data on Han population shares from the 2005 census.

7. Mean real per capita income: Due to lack of available data for consecutive years during the 1980s and 1990s, income data only for 1989 (1999) were used to measure average annual income for 1985-90 (1995-2000). For 2000-05, we use mean incomes for each year. Income data are adjusted for cost of living differences using provincial CPI.

8. Mean educational attainment: Educational attainment was measured as mean annual percentage of population enrolled in postsecondary institutions during 1985-90, 1995-2000, and 2000-05. For all three periods, most people in each province were not enrolled in colleges or universities, reflecting substantial barriers to access. However, as reforms deepened, enrollments rose from approximately $0.25 \%$ during $1985-90$ to approximately $1 \%$ during 2000-05. The variance of mean annual enrollment percentages rose at an increasing rate, which may have contributed to rising income inequality in China.

Data on the remaining variables are from Lin et al. (2004). Data sources and measurement of these variables were detailed in their article.

\section{COEFFICIENT ESTIMATES}

Tables 4 and 5 provide results from ordinary least square (OLS) estimation of Equations (7)-(9). Table 4 presents results for the full panel, whereas Table 5 presents results for the smaller panel comprising the last two periods. The important difference between the two tables is that in Table 4, the migrant stock measure and the interaction between migrant stock and distance are not included.
Our results reveal three broad patterns. First, the results confirm the hypothesis that a strengthening (loosening) of Hukou restrictions will deter (stimulate) migration. What is particularly surprising is the high degree of sensitivity of migration rates to Hukou restrictions. Second, Table 5 demonstrates that the estimated size of the migrant community is one of the strongest determinants of interprovincial migration rates. Note that in a comparison of Tables 4 and 5, the omission or addition of the migrant community variable will cause some coefficient estimates and goodness of fit to change dramatically. This comes as no surprise, for researchers since Sjaastad (1962) and Greenwood (1969), as well as sociologists, have argued that migrant networks tend to exert strong influences on the scale of migration. Third, our results demonstrate that the "basic specification" (Equation (7)) used in earlier studies is clearly an incomplete story about internal migration in China.

We organize the discussion of more specific results as follows. We first discuss coefficient estimates for Hukou restrictions. We then discuss the influences of past migration flows and the other controls for provincial characteristics. Before discussing specific results, we must emphasize that interpretation of the numerical coefficients in Tables 4 and 5 requires some care due to the double-log functional form for the regression equations and because some of the independent variables are ratios. Each coefficient is a migration elasticity, the percentage change in the percentage of persons moving from province $\mathrm{j}$ to province $\mathrm{i}$ (out of all persons moving from $\mathrm{j}$ ). Furthermore, some coefficients are estimates of the percentage change in the migration rate when there is a $1 \%$ change in a ratio. For example, the coefficient on the destination/origin income ratio measures the estimated percentage change in the migration rate when relative destination income changes by $1 \%$. Note that all estimated equations in both tables include origin province fixed effects and time period controls and are corrected for heteroskedasticity. Finally, data on some percentage variables were multiplied by 100 to allow for greater ease in the interpretation of coefficients.

\section{A. The Influence of Hukou}

Tables 4 and 5 confirm that Hukou restrictions can have a substantial impact on the 
TABLE 4

OLS Results for Full Sample (1985-90, 1995-2000, and 2000-05 Migration Periods) ${ }^{\mathrm{a}}$

\begin{tabular}{|c|c|c|c|c|c|}
\hline Regressor & $\mathbf{I}$ & II & III & IV & $\mathbf{V}$ \\
\hline $\begin{array}{l}\text { Log (odds of obtaining Hukou in } \\
\text { destination } \times 100)(\text { Measure A) }\end{array}$ & & $\begin{array}{l}1.505 \\
(1.209)\end{array}$ & $\begin{array}{c}11.836^{* *} \\
(2.933)\end{array}$ & & \\
\hline A $\times$ early dummy & & & $\begin{array}{l}-23.89^{* *} \\
(4.29)\end{array}$ & & \\
\hline A $\times$ late dummy & & & $\begin{array}{c}-9.097^{* *} \\
(2.629)\end{array}$ & & \\
\hline $\begin{array}{l}\text { Log (odds of securing a job with } \\
\text { Hukou } \times 100) \\
(\text { Measure B) }\end{array}$ & & & & $\begin{array}{l}3.531^{* *} \\
(0.949)\end{array}$ & $\begin{array}{l}4.729^{* *} \\
(1.239)\end{array}$ \\
\hline $\mathrm{B} \times$ early dummy & & & & & $\begin{array}{c}-9.848^{* *} \\
(3.181)\end{array}$ \\
\hline $\mathrm{B} \times$ late dummy & & & & & $\begin{array}{c}-1.964^{* *} \\
(1.092)\end{array}$ \\
\hline Log distance & $\begin{array}{c}-1.306^{* *} \\
(0 .)\end{array}$ & $\begin{array}{c}-1.325^{* *} \\
(0.04)\end{array}$ & $\begin{array}{c}-1.341^{* *} \\
(0.041)\end{array}$ & $\begin{array}{l}-1.333^{* *} \\
(0.04)\end{array}$ & $\begin{array}{c}-1.339^{* *} \\
(0.041)\end{array}$ \\
\hline Log (destination/origin income ratio) & $\begin{array}{c}1.889^{* *} \\
(0.09)\end{array}$ & $\begin{array}{l}1.866^{* *} \\
(0.130)\end{array}$ & $\begin{array}{l}1.902^{* *} \\
(0.130)\end{array}$ & $\begin{array}{l}1.940^{* *} \\
(0.124)\end{array}$ & $\begin{array}{l}1.914^{* *} \\
(0.126)\end{array}$ \\
\hline $\begin{array}{l}\text { Log (university enrollment in origin } \\
\quad \times 100)\end{array}$ & $\begin{array}{c}-0.348^{* *} \\
(0.137)\end{array}$ & $\begin{array}{l}-0.272 \\
(0.161)\end{array}$ & $\begin{array}{c}-0.275^{*} \\
(0.161)\end{array}$ & $\begin{array}{l}-0.283 \\
(0.162)\end{array}$ & $\begin{array}{c}-0.286^{*} \\
(0.162)\end{array}$ \\
\hline $\begin{array}{l}\text { Log (university enrollment in } \\
\text { destination } \times 100 \text { ) }\end{array}$ & $\begin{array}{l}-0.193^{* *} \\
(0.05)\end{array}$ & $\begin{array}{l}-0.258^{* *} \\
(0.059)\end{array}$ & $\begin{array}{l}-0.290^{* *} \\
(0.062)\end{array}$ & $\begin{array}{l}-0.257^{* *} \\
(0.06)\end{array}$ & $\begin{array}{c}-0.265^{* *} \\
(0.059)\end{array}$ \\
\hline $\begin{array}{l}\log (1-\text { unemployment rate in } \\
\text { origin })\end{array}$ & $\begin{array}{l}-5.984^{* *} \\
(2.066)\end{array}$ & $\begin{array}{l}-4.426^{* *} \\
(2.10)\end{array}$ & $\begin{array}{l}-4.404^{* *} \\
(2.085)\end{array}$ & $\begin{array}{c}-4.675^{* *} \\
(2.098)\end{array}$ & $\begin{array}{c}-4.485^{* *} \\
(2.095)\end{array}$ \\
\hline $\begin{array}{l}\log (1 \text { - unemployment rate in } \\
\text { destination })\end{array}$ & $\begin{array}{c}5.644^{* *} \\
(1.49)\end{array}$ & $\begin{array}{l}6.623^{* *} \\
(1.582)\end{array}$ & $\begin{array}{l}2.866^{*} \\
(1.686)\end{array}$ & & \\
\hline $\begin{array}{l}\log \text { (ratio of destination to origin } \\
\text { urban population shares) }\end{array}$ & $\begin{array}{l}-0.148 \\
(0.102)\end{array}$ & $\begin{array}{l}-0.175 \\
(0.104)\end{array}$ & $\begin{array}{c}-0.240^{* *} \\
(0.106)\end{array}$ & $\begin{array}{l}-0.246^{* *} \\
(0.99)\end{array}$ & $\begin{array}{c}-0.244^{* *} \\
(0.102)\end{array}$ \\
\hline $\begin{array}{l}\text { Log (ratio of destination to origin } \\
\text { temperatures) }\end{array}$ & $\begin{array}{l}0.471^{* *} \\
(0.062)\end{array}$ & $\begin{array}{l}0.330^{* *} \\
(0.071)\end{array}$ & $\begin{array}{l}0.342^{* *} \\
(0.071)\end{array}$ & $\begin{array}{c}0.348^{* *} \\
(0.07)\end{array}$ & $\begin{array}{l}0.347^{* *} \\
(0.071)\end{array}$ \\
\hline $\begin{array}{l}\text { Log (ratio of destination to origin } \\
\text { manufacturing employment } \\
\text { shares) }\end{array}$ & & $\begin{array}{r}-0.095 \\
(0.1)\end{array}$ & $\begin{array}{c}-0.081 \\
(0.09)\end{array}$ & $\begin{array}{c}-0.107 \\
(0.1)\end{array}$ & $\begin{array}{c}-0.077 \\
(0.1)\end{array}$ \\
\hline $\begin{array}{l}\log \text { (ratio of destination to origin } \\
\text { minority population shares) }\end{array}$ & & $\begin{array}{c}-0.011 \\
(0.02)\end{array}$ & $\begin{array}{l}-0.011 \\
(0.017)\end{array}$ & $\begin{array}{c}-0.012 \\
(0.17)\end{array}$ & $\begin{array}{l}-0.014 \\
(0.018)\end{array}$ \\
\hline $\begin{array}{l}\text { Log (ratio of destination to origin } \\
\text { per capita FAI) }\end{array}$ & & $\begin{array}{l}0.030 \\
(0.05)\end{array}$ & $\begin{array}{c}0.059 \\
(0.048)\end{array}$ & $\begin{array}{c}0.036 \\
(0.046)\end{array}$ & $\begin{array}{c}0.026 \\
(0.046)\end{array}$ \\
\hline $\begin{array}{l}\text { Log (ratio of destination to origin } \\
\text { per capita FDI) }\end{array}$ & & $\begin{array}{l}0.066^{* *} \\
(0.018)\end{array}$ & $\begin{array}{l}0.058^{* *} \\
(0.048)\end{array}$ & $\begin{array}{l}0.061^{* *} \\
(0.018)\end{array}$ & $\begin{array}{l}0.056^{* *} \\
(0.018)\end{array}$ \\
\hline Log FAI ratio $\times$ Log FDI ratio & & $\begin{array}{l}0.017^{* *} \\
(0.005)\end{array}$ & $\begin{array}{l}0.019^{* *} \\
(0.006)\end{array}$ & $\begin{array}{l}0.017^{* *} \\
(0.005)\end{array}$ & $\begin{array}{l}0.016^{* *} \\
(0.005)\end{array}$ \\
\hline $\begin{array}{l}\log (\text { transportation share of fixed } \\
\text { asset investment in origin } \times 100)\end{array}$ & & $\begin{array}{l}-0.053 \\
(0.09)\end{array}$ & $\begin{array}{l}-0.065 \\
(0.088)\end{array}$ & $\begin{array}{c}-0.069 \\
(0.88)\end{array}$ & $\begin{array}{l}-0.068 \\
(0.088)\end{array}$ \\
\hline $\begin{array}{l}\log (\text { origin per capita GDP) } \\
\quad(\text { origin per capita FAI) }\end{array}$ & & $\begin{array}{c}0.029^{* *} \\
(0.01)\end{array}$ & $\begin{array}{c}0.031^{* *} \\
(0.01)\end{array}$ & $\begin{array}{l}0.03^{* *} \\
(0.01)\end{array}$ & $\begin{array}{c}0.029^{* *} \\
(0.01)\end{array}$ \\
\hline Early period dummy & $\begin{array}{l}-0.121 \\
(0.171)\end{array}$ & $\begin{array}{l}0.367 \\
(0.26)\end{array}$ & $\begin{array}{l}0.367 \\
(0.26)\end{array}$ & $\begin{array}{l}0.522 * \\
(0.248)\end{array}$ & $\begin{array}{c}0.272 \\
(0.266)\end{array}$ \\
\hline Late period dummy & $\begin{array}{c}-0.490^{* *} \\
(0.185)\end{array}$ & $\begin{array}{c}0.051 \\
(0.233)\end{array}$ & $\begin{array}{c}0.065 \\
(0.236)\end{array}$ & $\begin{array}{c}0.131 \\
(0.231)\end{array}$ & $\begin{array}{c}0.05 \\
(0.245)\end{array}$ \\
\hline Constant & $\begin{array}{l}9.95^{* *} \\
(0.405)\end{array}$ & $\begin{array}{l}-8.50 \\
(13.74)\end{array}$ & $\begin{array}{c}8.473^{* *} \\
(0.65)\end{array}$ & $\begin{array}{l}-2.616 \\
(13.44)\end{array}$ & $\begin{array}{l}8.535^{* *} \\
(0.643)\end{array}$ \\
\hline Adjusted $R$-squared & 0.5499 & 0.5558 & 0.5608 & 0.5551 & 0.557 \\
\hline SSE & $2,476.5$ & $2,435.6$ & $2,406.5$ & $2,440.9$ & $2,429.6$ \\
\hline Sample size & 2,385 & 2,385 & 2,385 & 2,385 & 2,385 \\
\hline
\end{tabular}

Notes: Dependent variable $=\log$ gross interprovincial migration rate. Standard errors in parentheses.

${ }^{a}$ Provincial fixed effects are included and standard errors are corrected.

** Significant at $1 \%$; significant at $5 \%$. 
TABLE 5

OLS Results for Later Two Periods ${ }^{\mathrm{a}}$

\begin{tabular}{|c|c|c|c|c|c|c|}
\hline Regressor & I & II & III & IV & $\mathbf{V}$ & VI \\
\hline $\begin{array}{l}\text { Log (odds of obtaining Hukou } \\
\quad \times 100) \text { (Measure A) }\end{array}$ & & $\begin{array}{c}7.975^{* *} \\
(1.24)\end{array}$ & $\begin{array}{l}6.932^{* *} \\
(1.138)\end{array}$ & & & \\
\hline A $\times$ middle dummy & & & $\begin{array}{c}21.88^{* *} \\
(2.18)\end{array}$ & & & \\
\hline $\begin{array}{l}\text { Log (odds of migrant securing job } \\
\text { in destination with Hukou } \times 100) \\
(\text { Measure B) }\end{array}$ & & & & $\begin{array}{l}8.00^{* *} \\
(1.16)\end{array}$ & $\begin{array}{l}6.536^{* *} \\
(1.094)\end{array}$ & $\begin{array}{l}9.625^{* *} \\
(1.466)\end{array}$ \\
\hline $\mathrm{B} \times$ middle dummy & & & & & $\begin{array}{l}5.18^{* *} \\
(0.954)\end{array}$ & $\begin{array}{l}3.274^{* *} \\
(1.155)\end{array}$ \\
\hline Log relative size of migrant network & $\begin{array}{l}0.499^{* *} \\
(0.021)\end{array}$ & $\begin{array}{l}0.670^{* *} \\
(0.134)\end{array}$ & $\begin{array}{l}0.746^{* *} \\
(0.131)\end{array}$ & $\begin{array}{l}0.670^{* *} \\
(0.134)\end{array}$ & $\begin{array}{l}0.692^{* *} \\
(0.133)\end{array}$ & \\
\hline Log distance & $\begin{array}{c}-0.53^{* *} \\
(0.047)\end{array}$ & $\begin{array}{l}-0.48^{* *} \\
(0.103)\end{array}$ & $\begin{array}{c}-0.51^{* *} \\
(0.01)\end{array}$ & $\begin{array}{l}-0.48^{* *} \\
(0.103)\end{array}$ & $\begin{array}{c}-0.48^{* *} \\
(0.101)\end{array}$ & $\begin{array}{l}-1.28^{* *} \\
(0.05)\end{array}$ \\
\hline Log distance $\times$ Log network & & $\begin{array}{l}-0.014 \\
(0.018)\end{array}$ & & $\begin{array}{l}-0.014 \\
(0.018)\end{array}$ & $\begin{array}{l}-0.016 \\
(0.017)\end{array}$ & \\
\hline $\begin{array}{l}\text { Log (ratio of destination to origin } \\
\text { incomes) }\end{array}$ & $\begin{array}{l}1.251^{* *} \\
(0.085)\end{array}$ & $\begin{array}{l}1.503^{* *} \\
(0.117)\end{array}$ & $\begin{array}{l}1.390^{* *} \\
(0.116)\end{array}$ & $\begin{array}{l}1.505^{* *} \\
(0.114)\end{array}$ & $\begin{array}{l}1.370^{* *} \\
(0.113)\end{array}$ & $\begin{array}{l}2.08^{* *} \\
(0.148)\end{array}$ \\
\hline Log education in origin & $\begin{array}{l}-0.48^{* *} \\
(0.225)\end{array}$ & $\begin{array}{l}-0.50^{* *} \\
(0.220)\end{array}$ & $\begin{array}{l}-0.48^{* *} \\
(0.214)\end{array}$ & $\begin{array}{l}-0.50^{* *} \\
(0.220)\end{array}$ & $\begin{array}{c}-0.47^{* *} \\
(0.218)\end{array}$ & $\begin{array}{c}-0.59^{* *} \\
(0.285)\end{array}$ \\
\hline Log education in destination & $\begin{array}{l}-0.016 \\
(0.06)\end{array}$ & $\begin{array}{l}0.058 \\
(0.66)\end{array}$ & $\begin{array}{l}-0.08 \\
(0.068)\end{array}$ & $\begin{array}{l}0.058 \\
(0.06)\end{array}$ & $\begin{array}{c}0.051 \\
(0.062)\end{array}$ & $\begin{array}{c}0.137 \\
(0.085)\end{array}$ \\
\hline $\begin{array}{l}\log (1-\text { unemployment rate in } \\
\text { origin) }\end{array}$ & $\begin{array}{l}1.356 \\
(3.14)\end{array}$ & $\begin{array}{l}2.854 \\
(3.02)\end{array}$ & $\begin{array}{l}3.083 \\
(2.96)\end{array}$ & $\begin{array}{l}2.841 \\
(3.01)\end{array}$ & $\begin{array}{l}3.625 \\
(3.00)\end{array}$ & $\begin{array}{l}-1.441 \\
(3.61)\end{array}$ \\
\hline $\begin{array}{l}\log (1 \text { - unemployment rate in } \\
\text { destination })\end{array}$ & $\begin{array}{l}7.618^{* *} \\
(1.838)\end{array}$ & $\begin{array}{c}8.071^{* *} \\
(1.99)\end{array}$ & $\begin{array}{c}2.771 \\
(1.939)\end{array}$ & & & \\
\hline $\begin{array}{l}\text { Log (ratio of destination to origin } \\
\text { urban shares) }\end{array}$ & $\begin{array}{l}-0.33^{* *} \\
(0.097)\end{array}$ & $\begin{array}{c}-0.02 \\
(0.1)\end{array}$ & $\begin{array}{c}0.018 \\
(0.098)\end{array}$ & $\begin{array}{l}-0.02 \\
(0.09)\end{array}$ & $\begin{array}{c}0.090 \\
(0.092)\end{array}$ & $\begin{array}{c}0.088 \\
(0.123)\end{array}$ \\
\hline $\begin{array}{l}\text { Log (ratio of destination to origin } \\
\text { temperatures) }\end{array}$ & $\begin{array}{l}0.674^{* *} \\
(0.068)\end{array}$ & $\begin{array}{c}0.620^{* *} \\
(0.07)\end{array}$ & $\begin{array}{l}0.686^{* *} \\
(0.070)\end{array}$ & $\begin{array}{l}0.620^{* *} \\
(0.071)\end{array}$ & $\begin{array}{l}0.613^{* *} \\
(0.071)\end{array}$ & $\begin{array}{l}0.484^{* *} \\
(0.088)\end{array}$ \\
\hline $\begin{array}{l}\text { Log (ratio of destination to origin } \\
\text { manufacturing employment } \\
\text { shares) }\end{array}$ & & $\begin{array}{c}-0.244^{* *} \\
(0.091)\end{array}$ & $\begin{array}{c}-0.200 * \\
(0.090)\end{array}$ & $\begin{array}{l}-0.244^{* *} \\
(0.091)\end{array}$ & $\begin{array}{l}-0.214^{* *} \\
(0.09)\end{array}$ & $\begin{array}{l}-0.366^{* *} \\
(0.115)\end{array}$ \\
\hline $\begin{array}{l}\log \text { (ratio of destination to origin } \\
\text { minority population shares) }\end{array}$ & & $\begin{array}{l}-0.058^{* *} \\
(0.018)\end{array}$ & $\begin{array}{c}-0.068^{* *} \\
(0.018)\end{array}$ & $\begin{array}{c}-0.058^{* *} \\
(0.018)\end{array}$ & $\begin{array}{c}-0.056^{* *} \\
(0.018)\end{array}$ & $\begin{array}{c}0.026 \\
(0.021)\end{array}$ \\
\hline $\begin{array}{l}\text { Log (ratio of destination to origin } \\
\text { real per capita FAI) }\end{array}$ & & $\begin{array}{c}-0.293^{* *} \\
(0.052)\end{array}$ & $\begin{array}{c}-0.260^{* *} \\
(0.050)\end{array}$ & $\begin{array}{l}-0.292^{* *} \\
(0.05)\end{array}$ & $\begin{array}{c}-0.311^{* *} \\
(0.049)\end{array}$ & $\begin{array}{l}0.186^{* *} \\
(0.074)\end{array}$ \\
\hline $\begin{array}{l}\text { Log (ratio of destination to origin } \\
\text { real per capita FDI) }\end{array}$ & & $\begin{array}{c}0.082^{* *} \\
(0.03)\end{array}$ & $\begin{array}{c}0.104^{* *} \\
(0.03)\end{array}$ & $\begin{array}{l}0.082^{* *} \\
(0.028)\end{array}$ & $\begin{array}{l}0.109^{* *} \\
(0.028)\end{array}$ & $\begin{array}{c}0.009 \\
(0.037)\end{array}$ \\
\hline Log FAI ratio $\times$ Log FDI ratio & & $\begin{array}{l}-0.018^{* *} \\
(0.004)\end{array}$ & $\begin{array}{c}-0.011^{* *} \\
(0.004)\end{array}$ & $\begin{array}{l}-0.018^{* *} \\
(0.004)\end{array}$ & $\begin{array}{l}-0.016^{* *} \\
(0.004)\end{array}$ & $\begin{array}{l}0.025^{* *} \\
(0.008)\end{array}$ \\
\hline $\begin{array}{l}\log (\text { transportation share of fixed } \\
\text { asset investment in origin } \times 100 \text { ) }\end{array}$ & & $\begin{array}{l}-0.214 \\
(0.123)\end{array}$ & $\begin{array}{c}-0.211^{*} \\
(0.120)\end{array}$ & $\begin{array}{l}-0.214 \\
(0.123)\end{array}$ & $\begin{array}{c}-0.207^{*} \\
(0.122)\end{array}$ & $\begin{array}{l}-0.237 \\
(0.158)\end{array}$ \\
\hline $\begin{array}{l}\log (\text { origin per capita GDP) } \\
\quad \text { (origin per capita FAI) }\end{array}$ & & $\begin{array}{l}-0.013 \\
(0.013)\end{array}$ & $\begin{array}{l}-0.012 \\
(0.013)\end{array}$ & $\begin{array}{l}-0.013 \\
(0.013)\end{array}$ & $\begin{array}{l}-0.015 \\
(0.013)\end{array}$ & $\begin{array}{c}0.01 \\
(0.016)\end{array}$ \\
\hline Middle period dummy & $\begin{array}{l}-0.405 \\
(0.107)\end{array}$ & $\begin{array}{l}-0.590 \\
(0.345)\end{array}$ & $\begin{array}{l}-0.549 \\
(0.338)\end{array}$ & $\begin{array}{l}-0.592 \\
(0.343)\end{array}$ & $\begin{array}{l}-0.262 \\
(0.343)\end{array}$ & $\begin{array}{l}-0.036 \\
(0.04)\end{array}$ \\
\hline Constant & $\begin{array}{l}7.849^{* *} \\
(0.354)\end{array}$ & $\begin{array}{l}-78.98^{* *} \\
(18.12)\end{array}$ & $\begin{array}{l}8.027^{* *} \\
(1.071)\end{array}$ & $\begin{array}{c}-78.73^{* *} \\
(17.1)\end{array}$ & $\begin{array}{l}8.09^{* *} \\
(1.09)\end{array}$ & $\begin{array}{c}9.532^{* *} \\
(1.16)\end{array}$ \\
\hline Adjusted $R$-squared & 0.737 & 0.7591 & 0.7716 & 0.7593 & 0.7633 & 0.606 \\
\hline SSE & 910 & 813.84 & 785.11 & 828.62 & 814.26 & 1,375 \\
\hline Sample size & 1,580 & 1,580 & 1,580 & 1,580 & 1,580 & 1,580 \\
\hline
\end{tabular}

Notes: Dependent variable $=\log$ gross interprovincial migration rate. Standard errors in parentheses.

aprovincial fixed effects are included and standard errors are corrected.

** Significant at $1 \%$; *significant at $5 \%$. 
scale of interprovincial migration. Consider first columns II and III in both tables, where Hukou is measured by the lagged relative frequency of registered households. While column II in Table 4 indicates an insignificant effect of Hukou, when the Hukou $\times$ time period interactions are added, Hukou's effect is strong and significant. Specifically, column III predicts that a $1 \%$ point increase in the perceived probability of securing Hukou (e.g., suppose the odds rise by one unit from 88.5 to 89.5 percentage points) will induce an increase in the migration rate of $11.8 \%$. Table 5 shows similar findings. From column II, for example, a one-point increase in the odds of securing Hukou will induce an increase in the migration rate of about $8 \%$. Consider now columns IV and V in Tables 4 and 5, where Hukou is measured as the joint probability of an unregistered migrant securing Hukou and a job available only to someone with Hukou. From Table 4, when the odds of securing Hukou rise by a percentage point the migration rate rises between $3.53 \%$ and $4.73 \%$. From Table 5, a $1 \%$ point increase in the joint odds will induce an increase in the migration rate of between $6.5 \%$ and $8 \%$.

Tables 4 and 5 also reveal that the sensitivity of migration rates to changes in migration restrictions can vary substantially across periods. In Table 4, the default period is 1995-2000, so the coefficients on the interactions between the time dummies and Hukou (rows 3-4, column III) are estimates of the difference between the elasticity of migration with respect to the odds of securing Hukou in one period relative to the middle period. The migration elasticity is $23.89 \%$ lower in $1985-90$ than in 1995-2000, but only 9\% lower in 2000-05 than in 1995-2000. The sensitivity of migration to Hukou rose between the 1980s and 1990s and fell between the 1990s and 2000s, but the fall between the later two periods was less in absolute value. Thus, measured over the three decades, migration on balance is more sensitive to Hukou now than back in the 1980s. This suggests that as the comprehensive economic reforms deepened and Hukou underwent incremental reform, migration became more sensitive to Hukou. The same pattern emerges in column $\mathrm{V}$, rows $6-7$. When the joint odds measure of Hukou is used, migration is less sensitive to Hukou in the early and later periods compared to the middle period, but the diminution in sensitivity is much less in the latest period. In
TABLE 6

Variation in Estimated Marginal Effect of Hukou across Periods ${ }^{\mathrm{a}}$

\begin{tabular}{lccc}
\hline & $\begin{array}{c}\text { 1985-90 } \\
\text { (A) }\end{array}$ & $\begin{array}{c}\mathbf{2 0 0 0 - 0 5} \\
\text { (B) }\end{array}$ & (A)-(B) \\
\hline Marginal effect relative & & & \\
to 1995-2000 & & & \\
period of: & & & \\
Log (odds of securing & $-23.89^{* *}$ & $-9.097^{* *}$ & $-14.80^{* *}$ \\
Hukou $\times$ 100) & $(4.294)$ & $(2.629)$ & $(3.45)$ \\
Log (odds of a migrant & $-9.85^{* *}$ & $-1.964^{*}$ & $-7.885^{* *}$ \\
$\quad$ securing a job with & $(3.18)$ & $(1.09)$ & $(3.20)$ \\
Hukou $\times$ 100) & & & \\
\hline
\end{tabular}

Note: Standard errors in parentheses.

${ }^{\mathrm{a} C}$ Coefficients are taken from estimates of Equations (III) and (V) in Table 4, provincial fixed effects are included, and standard errors are corrected.

** Significant at $1 \%$; ${ }^{*}$ significant at $5 \%$.

Table 5, the default period is 2000-05. According to column III, row 3 , the elasticity of migration with respect to the odds of securing Hukou was nearly $22 \%$ higher in 2000-05 than in 1995-2000. According to column V, row 5, the elasticity with respect to the odds of an unregistered migrant securing a job and Hukou was approximately 5\% higher in 2000-05.

Table 6 pulls together the coefficients from Table 4 and shows results of $t$ tests on differences in the time period $\times$ Hukou interactions across periods. Note that the default period is 1995-2000. The number in the last column to the right in row 3 is the estimated difference between: (a) the change in the migration elasticity (with respect to the odds of securing Hukou) from 1985-90 to 1995-2000; and (b) the change in that elasticity from 1995-2000 to 2000-05. While the elasticity was lower in the first and third periods compared to the second period, it is lower than the middle period by $14.8 \%$ in $2000-05$. Note that the estimated difference between (i) the 1985-90 and 1995-2000 difference in the elasticity; and (ii) the 2000-05 and 1995-2000 difference in the elasticity is significant at $1 \%$. The number in the last column to the right in row 4 shows the same type of information for the migration elasticity with respect to the joint odds measure of Hukou. While that elasticity was lower in the first and third periods, it was lower by $8 \%$ less in the last period, a result significant at $1 \%$.

The results in Table 6 imply an inverse U-shaped relationship between the elasticity of migration with respect to Hukou and time. Between the 1980s and 1990s, migration's 
sensitivity to Hukou apparently rose, which we believe is a result of the deepening of economic reforms and deregulation of migration. Following the arrival of the new millennium, sensitivity fell, perhaps because the above-normal returns to migration had by then dissipated for most prospective migrants. ${ }^{16}$ However, the sensitivity of migration to Hukou was still higher in the 2000s compared to the 1980s, consistent with our general hypothesis that China's move toward a market system heightened incentives to migrate.

\section{B. The Influence of Migrant Networks}

Table 5 illustrates the strong and robust effects of migrant networks on the scale of interprovincial migration. Across different specifications, the elasticity of migration with respect to past migration flows varies between approximately $0.5 \%$ and $0.75 \%$. For example, according to column $\mathrm{V}$, a one-point increase in the migrant stock measure is estimated to cause the migration rate to rise by approximately $0.75 \%$. Note that we find no evidence of an interaction between migrant stock and distance. Of equal importance is what we learn from column VI, which indicates the effects on coefficient estimates and goodness of fit when the migrant stock variable is omitted. We find that some coefficients on remaining variables change dramatically and the adjusted R-squared falls from approximately $75 \%$ to $60 \%$. These results illustrate that failure to control for migrant networks will very likely lead to omitted variables bias.

\section{The Influence of Provincial Controls Not Included in Previous Studies}

The results in columns II-V in Tables 4 and 5 illustrate that coefficient estimates from earlier studies may suffer from omitted variables bias because some important controls are excluded. Turning first to column III in Table 4, we find that the migration rate is positively related to relative FDI in the destination; A $1 \%$ increase in the ratio of destination to origin FDI generates an approximately $0.06 \%$ increase in the migration rate. While relative FAI appears to have no effect, the migration rate is positively related to the interaction of the two investments. The positive interaction term implies that an increase in relative FDI boosts the sensitivity of

16. We thank T. N. Srinivasan for pointing this out to us. migration to relative FAI. Note also the positive and significant interaction between per capita GDP and FAI per capita. This implies that in less prosperous provinces, domestically financed investment has a smaller effect on migration than in more prosperous provinces. Column V in Table 4 echoes this.

In Table 5, some of our provincial controls exert important effects. According to column III, the migration rate is negatively related to the relative destination share of manufacturing employment, the relative destination share of minority population, the relative amount of fixed investment in the destination, the investment interaction, and the share of fixed asset investment comprising transportation infrastructure in the origin. As with the full panel, the migration rate and relative FDI in the destination are positively related, although the effect is smaller than in the full panel. The coefficient for relative fixed asset investment in the destination is contrary to what is hypothesized, but note from column VI that when past migration flows are omitted, the coefficient on this investment ratio becomes positive and significant. We found this to be true for different permutations of the migration equation when past migration flows were excluded. Further investigation confirmed the reason for the negative coefficients on the FAI term in columns III and $\mathrm{V}$ - unexplained multicollinearity between past migration and FAI.

\section{CONCLUDING REMARKS}

We view this study as making two important contributions to the literature. First, very little is known in the migration literature about the effects of restrictions on the scale and structure of migration. Due to lack of theoretical work, lack for data for many countries, and large international differences in the type and quality of data, there are no studies addressing questions such as: (i) How elastic are migration rates with respect to a change in quantitative restrictions; (ii) Does migration become more or less sensitive to restrictions as they ease over time; and (iii) Do restrictions influence the effects of other determinants on migration? This study attempts to answer these sorts of questions. We seized upon a very convenient natural experiment, China, a country with an internal passport system that has been undergoing incremental deregulation. For a cross-section study of the effects of immigration restrictions, China 
is a beautiful case of "borders within a border," allowing a researcher to test for the effects of restrictions across spatial units without having to use different data sets for different countries or having to control for country-specific influences such as type of political system, labor market structure, regulations, and educational system. Furthermore, China offers the researcher the opportunity to study the effects of restrictions in a transition economy, one that has been experiencing dramatic changes in the structure of its markets.

What we learn from our examination of the Chinese test case is that migration can be significantly responsive to a loosening of restrictions. We find that even a modest reduction in restrictions can greatly strengthen the incentive to migrate. We find strong evidence that the sensitivity of migration to Hukou has on balance risen over the last 30 years, with the greatest increase occurring during the 1990s. We also find that adding migration restrictions to an empirical specification can influence considerably the effects that other determinants of migration have on migration. Therefore, restrictions change not only the scale of migration, but its structure. This inspires two questions for future research: (1) Are our results for postreform China generalizable to an international study?; and (2) What can we predict will happen to migration as a result of future adjustments in the Hukou system?

Our second contribution is to further clarify what drives migration in postreform China. We see our study as generating two specific benefits in this regard. First, we show that Hukou's influence can be substantial, implying that if the goal of deregulation is to encourage more labor mobility, then further deregulation is warranted. Second, the empirical literature on Chinese migration is still very small, comprising studies that estimate relatively parsimonious equations of migration rates. Most of these studies lack controls for migrant communities in the destination, indicators of a spatial unit's economic and demographic structures, FDI and domestic investments, export market dependency, and other influences. We add migrant networks, FDI and domestic fixed asset investments, industry and ethnic mix, climate, origin fixed effects, and more, to the modified gravity model of Chinese migration. We find these controls can contribute significantly to accounting for migration patterns across spatial units and time; hence failure to include them is very likely to result in omitted variables bias. Finally, ours is the first comprehensive panel study of migration in China.

\section{REFERENCES}

Au, C.-C., and V. Henderson. "How Migration Restrictions Limit Agglomeration and Productivity in China." Journal of Development Economics, 80, 2006, 350-88.

Bao, S., J. Hou, and A. Shi. "Migration and Regional Development in China," in Chinese Economy after WTO Accession, edited by S. Bao, S. Lin, and C. Zhao. Aldershot, UK: Ashgate, 2006.

Chan, K. W. Cities with Invisible Walls. New York, NY: Oxford University Press, 1994.

Chan, K. W., and L. Zhang. "The Hukou System and RuralUrban Migration in China: Processes and Changes." The China Quarterly, 160, 1999, 818-55.

Chen, A., and N. E. Coulson. "Determinants of Urban Migration: Evidence from Chinese Cities." Urban Studies, 39, 2002, 2189-97.

Cheng, T., and M. Selden. "The Origins and Social Consequences of China's Hukou System." The China Quarterly, 139, 1994, 644-68.

Clark, X., T. Hatton, and J. Williamson. "Explaining U.S. Immigration." Review of Economics and Statistics, 89, 2007, 1971-98.

Crozet, M. "Do Migrations Follow Market Potentials? An Estimation of a New Economic Geography Model." Journal of Economic Geography, 4, 2004, 439-58.

Davin, D. Internal Migration in Contemporary China. New York, NY: St. Martin's Press, 1999.

Day, L., and M. Xia. Migration and Urbanization in China, Armonk, NY: M.E. Sharpe, 1994.

Fan, C. C. "Modeling Interprovincial Migration in China." Eurasian Geography and Economics, 46, 2005, 1985-2000.

Goldstein, S. "Urbanization in China, 1982-87: Effects of Migration and Reclassification." Population and Development Review, 16, 1990, 673-701.

Goldstein, S., and A. Goldstein. "China," in International Handbook on Internal Migration, edited by C. B. Nam, W. Serrow, and D. F. Sly. New York, NY: Greenwood Press, 1990.

Goodkind, D., and L. A. West. "China's Floating Population: Definitions, Data and Recent Findings." Urban Studies, 39, 2002, 2237-50.

Greenwood, M. J. "An Analysis of the Determinants of Geographic Mobility in the United States." Review of Economics and Statistics, 51, 1969, 189-94.

-. "Internal Migration in Developed Economies," in Handbook of Population and Family Economics, edited by M. Rosenzweig and O. Stark. Amsterdam: Elsevier B.V., 1997.

Li, H., and S. Zahniser. "The Determinants of Temporary Rural-to-Urban Migration in China." Urban Studies, 39, 2002, 2219-35.

Liang, Z. "The Age of Migration in China." Population and Development Review, 27, 2001, 499-524.

Liang, Z., and M. J. White. "Internal Migration in China." Demography, 33, 1996, 1950-88.

_. "Market Transition, Government Policies, and Interprovincial Migration in China." Economic Development and Cultural Change, 45, 1997, 1983-88.

Liang, Z., Y. P. Chen, and Y. Gu. "Rural Industrialisation and Internal Migration in China." Urban Studies, 39, 2002, 2175-87.

Lin, J., G. Wang, and Y. Zhao. "Regional Inequality and Labor Transfers in China." Economic Development and Cultural Change, 52, 2004, 587-603. 
Poncet, S. "Provincial Migration Dynamics in China: Borders, Costs and Economic Motivations." Regional Science and Urban Economics, 36, 2006, 385-98.

Sjaastad, L. "The Costs and Returns of Human Migration." Journal of Political Economy, 70, 1962, 80-93.

Tabuchi, T., and J.-F. Thisse. "Taste Heterogeneity, Labour Mobility and Economic Geography." Journal of Development Economics, 69, 2002, 166-77.

Wang, F. "The Breakdown of a Great Wall: Recent Changes in Household Registration System in China," in Floating Population and Migration in China: The Impact of Economic Reforms. Hamburg, edited by T. Scharping. Germany: Institute of Asian Studies, 1997.

Whalley, J., and S. Zhang. "Inequality Change in China and (Hukou) Labour Mobility Restrictions." NBER Working Paper 10683, 2004. http://www.nber.org/papers/ w10683
Wu, X., and D. J. Treiman. "The Household Registration System and Social Stratification in China." Demography, 41, 2004, 1955-96.

Zhao, Y. "Labor Migration and Returns to Rural Education in China." American Journal of Agricultural Economics, 79, 1997, 1278-87.

. "Labor Migration and Earnings Differences: The Case of Rural China." Economic Development and Cultural Change, 47, 1999a, 767-82.

"Leaving the Countryside: Rural-to-Urban Migration Decisions in China." American Economic Review, 89, 1999b, 281-86.

"Causes and Consequences of Return Migration: Recent Evidence from China." Journal of Comparative Economics, 30, 2002, 376-94.

"The Role of Migrant Networks in Labor Migration: The Case of China." Contemporary Economic Policy, 21, 2003, 500-11. 